\title{
632 人間の聴覚特性を考慮した放射騒音抑制のためのスマート構造最適化
}

\section{Multidisciplinary optimization of smart structures for radiated sound suppression considering human auditory property}

\author{
小野 仁章（東工大）正 梶原 逸朗（東工大）
}

\begin{abstract}
Kimiaki ONO, Tokyo Institute of Technology, 2-12-1 O-okayama, Meguro-ku, Tokyo Itsuro KAJIWARA, Tokyo Institute of Technology
\end{abstract}

This paper proposes a multidisciplinary design optimization approach of smart structures for sound suppression. The smart structure consists of panel with one fixed end, two piezoelectric ceramic actuators and control system. The control system is designed according to the $\mathrm{H}_{2}$ specification with a reduced-order modal model derived from FEM and modal analysis. The sound pressure level of radiated sound from the vibrating panel is calculated by BEM. Derived sound pressure level is converted to loudness level according to ISO 226 , and then radiated sound power level is calculated. The design problem for improving the $H_{2}$ performance is defined, and then the piezoelectric ceramic actuators and the control system are simultaneously optimized by the presented approach, resulting in an enhanced performance for the sound suppression.

Key Words: Smart Structure, Sound and Vibration, Auditory Property, Genetic Algorithm, Optimization

\section{A 1 .はじめに}

本論文では片持ち平板をスマート構造の対象構造物とし， 振動制御による放射騒音抑制を目的とする。まず，有限要 素解析とモード解析に基づき，低次元モデルを作成し， $\mathrm{H}_{2}$ 仕様により制御系を設計する。その後，境界要素法により 放射騒音の音圧を求める，等ラウドネス曲線に基づき人間 の聴覚特性を考慮した最適化問題を定義し, 圧電アクチュ エータの配置と制御系の統合最適化を行う。最適化により 得られたアクチュエータの配置および制御系によりシミュ レーションを行い, 達成される放射騒音抑制効果を評価し, 統合最適設計の有効性を検証する.

\section{A 2. 対象構造物のモデル化と制御系設計}

本論文で対象とする構造物はアルミニウム製片持ち平板 である。平板の片面にはアクチュエータとして 2 枚の圧電 セラミックが貼付されており，冥面にはセンサとして加速 度計が設置されている．構造を有限要素法によりモデル化 し，モード座標変換による低次元化を行う。モード座標に 重み付けを行い，制御系を設計し，制御時における平板表 面における変位の周波数応答を求める. 得られた周波数応 答をもとに境界要素法により平板から放射される騒音の音 圧を計算し,その後, ラウドネスレベルに変換し評価する.

\section{A 3. 統合最適設計および結果}

目的関数および制約条件を設定し，アクチュエータの配 置, 重み行列を設計変数として最適化を行う。単位入力の 外乱が作用したときに平板から放射される音響パワーレベ ルを最小化することを目的とする，また，制約条件として
外乱入力 $w$ から制御入力 $u$ までの伝達関数行列の $H_{2}$ ノルム に上限を設ける。この最適化問題を遺伝的アルゴリズムに より解く. 20〜 $500 \mathrm{~Hz}$ における平板からの放射騒音低減の ための最適化結果を示す。得られた圧電アクチュエータの 最適配置をFig.A1に示し，最適化により達成される放射騒 音抑制効果を示すため, Fig.A2に音響パワーレベルの周波 数応答を示す。黒線が非制御時の周波数応答を示し, 赤線 が制御時の周波数応答を示す。制御を行うことで放射騒音 に寄与が大きい 5 次 $(243 \mathrm{~Hz})$ のピークが低減され, 効率 的に音響パワーレベルが低減できていることがわかる.

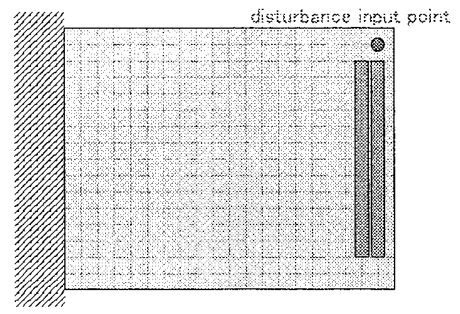

Fig.A1 Optimal location of actuators

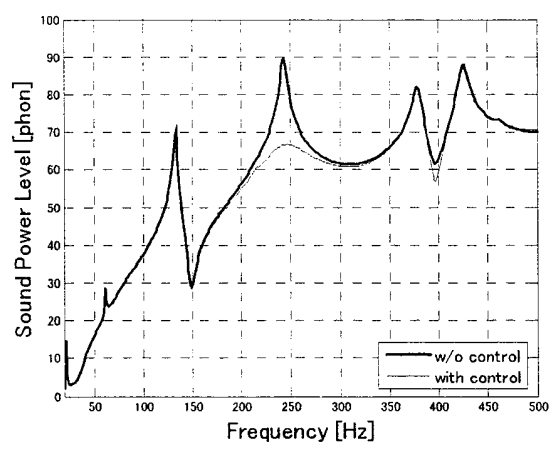

Fig.A2 Sound power level of radiated sound 


\section{1. 緒言}

近年, 各種機械の高性能化に伴い, 構造物の低振動化, 低騒音化が求められているが，構造設計のみで所望の振動 特性および放射騒音特性を達成することは非常に困難にな ってきている.そこで, 本論文では構造物をスマート化 (知 的構造化） ${ }^{122}$ 寸することにより所望の放射騒音特性を得るこ とを目的とする，等ラウドネス曲線に基づき，人間の聴覚 特性を考慮した上で，スマート構造の機構と制御を統合的 に最適化することによって，より効果的な放射騒音抑制を 達成する。

\section{2. モデル化}

本論文ではアルミニウム製片持ち平板を対象構造物とし， 寸法および物性值を Table 1 に示す。また，FEMにより解 析したモード形を Fig.1 に示す。ここで，固定端は左手前 であり，コンター図は面外の変位を表す．平板の片面にア クチュエータとして，2 枚の圧電セラミックを貼付し，裏 面にはセンサとして加速度計を設置する。

Table 1 Dimension and material properties

\begin{tabular}{|c|c|}
\hline Length [mm] & 200 \\
\hline Width [mm] & 160 \\
\hline Thickness [mm] & 1 \\
\hline Young's Modulus [GPa] & 70.3 \\
\hline Poisson's ratio & 0.345 \\
\hline Density [Kg/m ${ }^{3}$ ] & $2.7 \times 10^{3}$ \\
\hline Modal damping ratio & 0.01 \\
\hline
\end{tabular}

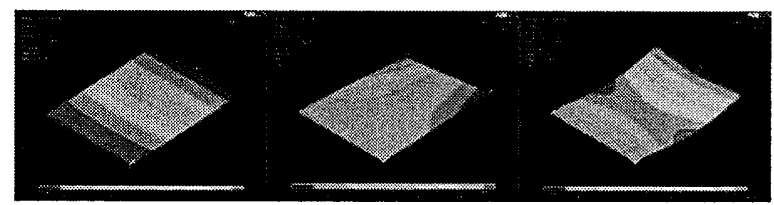

1st mode 2nd mode 3rd mode

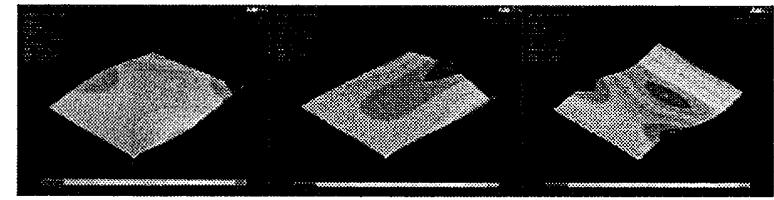

4th mode 5 th mode 6th mode

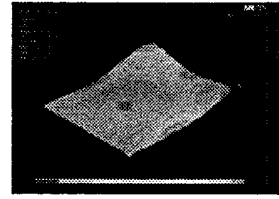

7 th mode

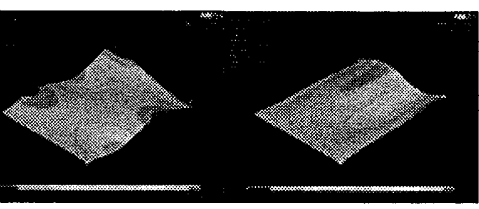

8th mode

9th mode

Fig.1 Mode shapes of the objective structure

$n$ 自由度システムの運動方程式を次式として記述寸る.

$$
M_{s} \ddot{x}+C_{s} \dot{x}+K_{s} x=B_{1 s} w+B_{2 s} u
$$

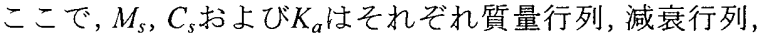

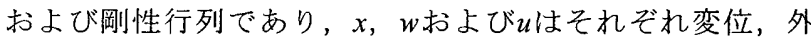
乱および制御入力ベクトルである。また，行列 $B_{2 s}$ は，制御 入力 $u$ と压電アクチュエータにより構造に作用するモーメ ントの関係により決定できる。

次に,モード座標変換 $x=\Phi \xi$ を用いて低次元システムを 作成し，制御系を設計する。ここで採用モード数を $r$ とす る。低次元化後の状態方程式は，モード座標 $\xi$ とその時間 微分字からなるべクトル $q$ を状態量として,

$$
\dot{q}=A q+B_{1} w+B_{2} u
$$

となる、ここで，

$$
\begin{aligned}
& q=\left\{\begin{array}{l}
\xi \\
\dot{\xi}
\end{array}\right\} \quad, \quad A=\left[\begin{array}{cc}
0 & I_{r} \\
-\Lambda & -\Phi^{T} C_{s} \Phi
\end{array}\right] \\
& B_{1}=\left[\begin{array}{c}
0 \\
\Phi^{T} B_{1 s}
\end{array}\right] \quad, \quad B_{2}=\left[\begin{array}{c}
0 \\
\Phi^{T} B_{2 s}
\end{array}\right]
\end{aligned}
$$

$\Lambda$ は系の固有值行列であり， $\Phi$ は質量正規化されたモード 行列である。

また，フィードバックのための出力方程式を次式として 記述する。

$$
y_{2}=C_{2}+D_{21} w+D_{22} u
$$

本論文では式(3)の観測出力として, 加速度センサ出力を用 いる. 加速度センサは，取り付け面の法線方向の加速度が 検出される．検出加速度 $y_{a}$ を $y_{a}=C_{a} \ddot{x}$ で表すと，式(3)の係 数行列は次のようになる。

$$
\begin{aligned}
& C_{2}=C_{a} \Phi\left[\begin{array}{ll}
-\Lambda & -\Phi^{T} C_{s} \Phi
\end{array}\right] \\
& D_{21}=C_{a}\left[\begin{array}{ll}
0 & \Phi
\end{array} B_{1}\right. \\
& D_{22}=C_{a}\left[\begin{array}{ll}
0 & \Phi
\end{array}\right] B_{2}
\end{aligned}
$$

\section{3. 制御系設計}

制御系は，所望の振動制御性能を達成すべく， $H_{2}$ 制御問 題に基づいて設計される.制御系のブロック線図をFig.2に 示す。

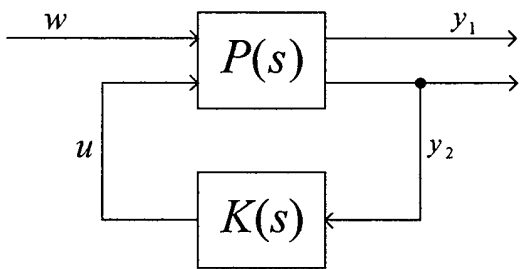

Fig. 2 Block diagram of control system

コントローラ $K(s)$ は，外乱 $w$ から制御量 $y_{1}$ までの伝達関数 行列の $H_{2}$ ノルムを最小にする以下の $H_{2}$ 制御問題に基づい 
て設計される.

$$
\min .\left\|T_{y_{1} w}\right\|_{2}
$$

制御量 $y_{I}$ を評価応答 $z_{I}$ および制御入力 $u$ を用いて,

$$
y_{1}=\left\{\begin{array}{c}
Q^{1 / 2} z_{1} \\
R^{1 / 2} u
\end{array}\right\}
$$

と表すと, 式(5)の制御問題は白色雑音外乱に対する以下の 制御問題と等価になる.

$$
\min . E\left[z_{1}{ }^{T} Q z_{1}+u^{T} R u\right\rfloor
$$

ここで，本論文では $Q=q_{w} I, R=100 I$ とする.

制御量 $y_{I}$ に扝ける制御応答としてモード座標を評価する

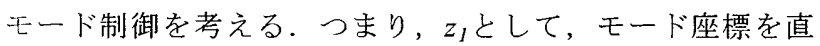
接参照し，モードごとの振動制御を達成するための評価応 答を次のように記述する。

$$
z_{1}=W_{10} q \quad, \quad W_{10}=\operatorname{diag}\left[\begin{array}{llll}
w_{1} & w_{2} & \ldots & w_{2 r}
\end{array}\right]
$$

すなわち，モードごとに重み付けを行うことによって，着 目するモードに対し重点的に制御を行うことができる。こ こで示したモード制御法は，周波数重み関数を用いた場合 と異なり，コントローラの次数を増加することなく，周波 数の異なるモードごとの制御を可能にしている.

以上をまとめると制御量 $y_{1}$ は次式のようになる.

$$
\begin{aligned}
& y_{1}=C_{1} q+D_{12} u \\
& C_{1}=\left[\begin{array}{c}
Q^{1 / 2} W_{10} \\
0
\end{array}\right], \quad D_{12}=\left[\begin{array}{c}
0 \\
R^{1 / 2} I
\end{array}\right]
\end{aligned}
$$

本論文では $H_{2}$ 制御による閉ループ系を構成するが，式(7) を最小にする最適制御則は

$$
u=-F q
$$

となり,フィードバックゲイン $F$ は次式で与えられる.

$$
F=-R^{-1} B_{2}{ }^{T} P
$$

ここで，Pは次に示すリカッチ方程式の解である.

$$
A^{T} P+A+W_{10}{ }^{T} Q W_{10}-P B_{2} R^{-1} B_{2}{ }^{T} P=0
$$

また, 制御入力の評価関数を $H_{u}=E\left[\begin{array}{ll}u^{T} & u\end{array}\right]$ として定義する と、これは次式として求めることができる。

$$
H_{u}=\operatorname{trace}\left[F X F^{T}\right]
$$

ここで，Xはリアプノフ方程式の解である．

$$
\begin{aligned}
& X G^{T}+G X+B_{1} B_{1}^{T}=0 \\
& G=A-B_{2} F
\end{aligned}
$$

\section{4. 統合最適設計}

\section{1 最適化問題}

構造系と制御系の設計変数をそれぞれ $\eta_{s}, \eta_{c}$ とおいて, 統合最適化問題を以下のように定義する.
目的関数: $J\left(\eta_{s}, \eta_{c}\right) \rightarrow$ 最小

制約条件: $g_{\text {min }} \leq g_{c} \leq g_{\text {max }}$

ここで $J\left(\eta_{s}, \eta_{c}\right)$ は構造変数および制御変数の両者に依存 する目的関数である. $g_{c}$ は構造変数, 制御変数, あるいは その両方に依存する制約条件である。

式(11)より得られた最適状態フィードバックゲインによ る制御時の構造表面のコンプライアンス周波数応答を閉ル ープの状態空間モデルより算出し, 境界要素法により観測 点での音圧の周波数応答を得る.

本論文では音圧観測点をFig.3 に示すように半球上に 9 点設置する．境界要素法により得られた観測点上での音圧 をFig.4 に示す等ラウドネス曲線 ${ }^{3)}$ に基づき, ラウドネスレ ベル（単位:phon）に変換する，それぞれの観測点上でのラ ウドネスレベルを $L_{p i}$ [phon] $(i=1,2, \cdots, 9)$ とおくと, 平板から 放射される音響パワーレベル $L_{w}$ [phon]は以下のように算出 できる。

$$
\begin{aligned}
& L_{w}=L_{p}+10 \log _{10} S \\
& L_{p}=10 \log _{10}\left(\frac{1}{N} \sum_{i=1}^{N} 10^{0.1 L_{p i}}\right)
\end{aligned}
$$

ここで， $L_{p}$ は音源を取り囲む面上の平均ラウドネスレベル [phon], Sは測定面の面積 $\left[\mathrm{m}^{2}\right], N$ は観測点数を表す.
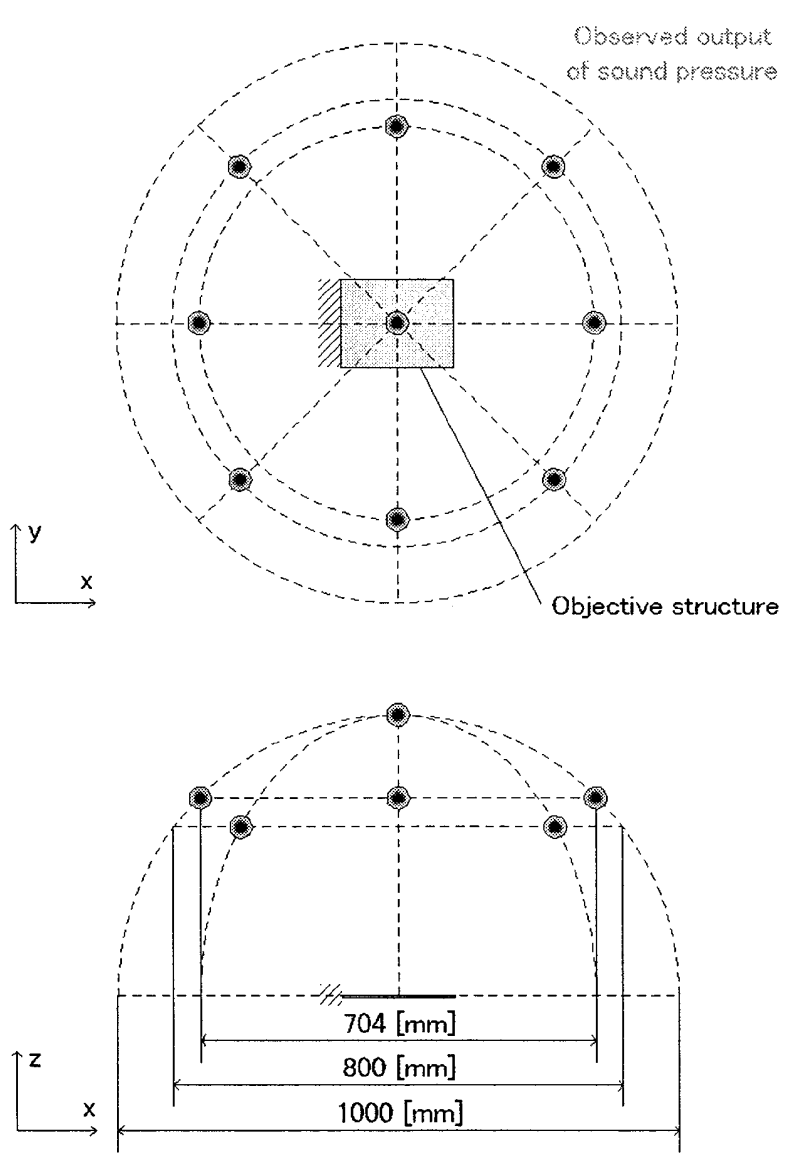

Fig.3 Observed outputs of sound pressure 


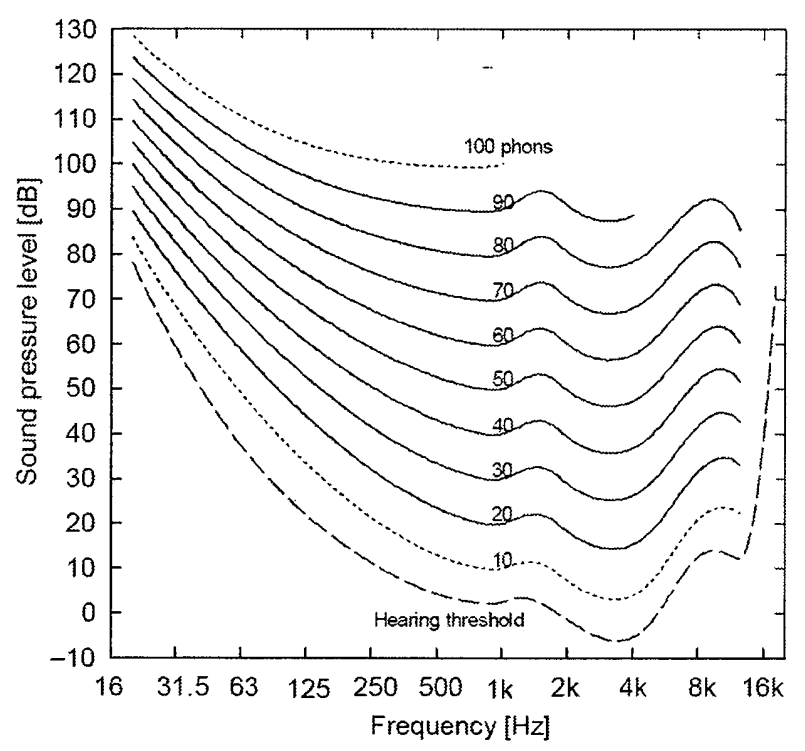

Fig.4 Equal-loudness-level contour

本論文では抑制対象周波数を $20 \sim 500 \mathrm{~Hz}$ とし，目的関数 を以下のように定義する。

$$
H_{s}=\sum_{\omega=\omega_{L}}^{\omega_{H}} L_{w}(\omega) \Delta \omega
$$

ここで, $\omega[\mathrm{Hz}]$ は周波数， $\omega_{L}[\mathrm{~Hz}]$ および $\omega_{H}[\mathrm{~Hz}]$ はそれぞ れ抑制対象とする下限周波数抢よび上限周波数を示す.

$\Delta \omega[\mathrm{Hz}]$ は周波数応答解析周波数間隔を示し， $\Delta \omega=1 \mathrm{~Hz}$ とした.目的関数をこのように定義することで, ISO226B ${ }^{4) 5)}$ のラウドネスレベル測定手法に準拠しつつ，計算負荷を抑 えることができる.スペクトルマスキング4)-6)については考 慮していないが, 対象周波数内に卓越したピークが存在し ないため問題ないと考えられる。また音の大きさについて の臨界帯域幅 ${ }^{4) 7}$ はTable 2 に示すように，500Hz以下では 100Hzでほぼ一定であるため，こ机にいても考慮する必 要はないと考えられる。

Table 2 Critical bandwidth

\begin{tabular}{|c|c|c|c|}
\hline Number & $\begin{array}{c}\text { Center } \\
\text { Frequency } \\
{[\mathrm{Hz}]}\end{array}$ & $\begin{array}{c}\text { Cut-off } \\
\text { Frequency } \\
{[\mathrm{Hz}]}\end{array}$ & $\begin{array}{c}\text { Bandwidth } \\
{[\mathrm{Hz}]}\end{array}$ \\
\hline 1 & 50 & 100 & 80 \\
\hline 2 & 150 & 200 & 100 \\
\hline 3 & 250 & 300 & 100 \\
\hline 4 & 350 & 400 & 100 \\
\hline 5 & 450 & 510 & 110 \\
\hline 6 & 570 & 630 & 120 \\
\hline 7 & & & \\
\hline
\end{tabular}

制約条件としてアクチュエータ長さlと制御コスト $H_{u}$ に 上限を設定し, 最適化問題は以下のように定義される.

$$
\begin{gathered}
\text { 目的関数: } H_{s} \rightarrow \text { 最小 } \\
\text { 制約条件 }: H_{u} \leq H_{u \max } \\
l \leq l_{\max }
\end{gathered}
$$

実システムにおいては, 一般に状態フィードバック制御 を行うことは出来ないので, 以下の 2 ステップ最適化アル ゴリズムを用いることにより, 出力フィードバック制御系 を設計する。

（Step1）状態フィードバック $u=-F q$ を仮定し, 統合的最 適化を実行することにより, 圧電アクチュエータの最適配 置, 最適なモード重み行列および最適状態フィードバック ゲインを求める。

（Step2）線形行列不等式（LMI）のアプローチに基づいて 出力フィードバックの動的補償器 $K(s)$ を再構築する. LMI の定式化により，効率的なアルゴリズム（LMIソルバ）を 用いてコントローラが設計される. 動的補償器による出力 フィードバック $u=K(s) y_{2}$ は，次式により表される.

$$
\begin{aligned}
& \dot{q}_{c}=A_{c} q_{c}+B_{c} y_{2} \\
& u=C_{c} q_{c}+D_{c} y_{2}
\end{aligned}
$$

ここで， $\dot{q}_{c}$ はコントローラの内部の状態量であり， $K(s)=C_{c}\left(s I-A_{c}\right)^{-1} B_{c}+D_{c}$ となる.

\section{2 設計変数}

2 枚の圧電アクチュエータ配置を構造系設計変数, $q_{w}$ と $W_{10}$ を制御系設計変数とし, 両者を同時に最適化する。ア クチュエータ配置は 320 要素に分割したFEMモデルの 357 点の節点番号を用いて表され，制御入力はアクチュエータ の両端にモーメントとして作用すると考える.

本論文では，最適化問題(18)を解くための手法として， 遺伝的アルゴリズムを用いる。構造系設計変数である節点 番号は離散值をとるので,この最適化問題を解く手法とし て遺伝的アルゴリズムは適していると考えられる.

設計変数をコード化し, 次のような $2 n p+m+l$ ビットの 染色体を定義する.

$$
\underbrace{\gamma_{1} \cdots \gamma_{p}}_{i_{x}}, \underbrace{\gamma_{p+1} \cdots \gamma_{2 p}}_{j_{x}}, \cdots, \underbrace{\gamma_{2 n p+1} \cdots \gamma_{2 n p+m}}_{q_{w}}, \underbrace{\gamma_{2 n p+m+1} \cdots \gamma_{2 n p+m+l}}_{W_{10}}
$$

ここで, $\gamma_{k}(k=1, \cdots, 2 n p+m+l)$ は 0 もしくは 1 をとる遺伝 子を表し， $n$ は貼り付ける圧電アクチュエータの枚数， $i_{x}$, $j_{x}$ は $x$ 枚目の圧電アクチュエータの両端に対応する節点番 号を表し，压電アクチュエータは交差しないものとする。 また， $p ， m ， l$ はそれぞれ節点番号， $q_{w}$ および $W_{10}$ を表現す るために必要なビット数である。これらの設計変数の最適 值を選択・交叉・突然変異といった遺伝的操作に基づく遺 伝的アルゴリズムにより探索する. 


\section{5. 最適化結果}

$H_{u \text { max }}=0.01, l_{\max }=130 \mathrm{~mm}$ として得られた最適化結果を 示す。最適化により得られた圧電アクチュエータ配置を

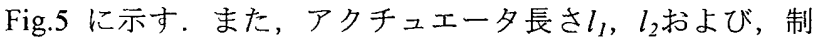
御系設計変数 $q_{w}, W_{10}$ は以下のように得られ, 非制御時の 目的関数 $H_{s_{-} \text {without }}=27290$ である.

$$
\begin{aligned}
& l_{1}=120 \mathrm{~mm} \\
& l_{2}=120 \mathrm{~mm} \\
& q_{w}=6.2 \times 10^{4}
\end{aligned}
$$

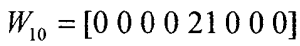

$$
\begin{aligned}
& H_{u}=H_{u \text { max }} \\
& H_{s}=26632
\end{aligned}
$$

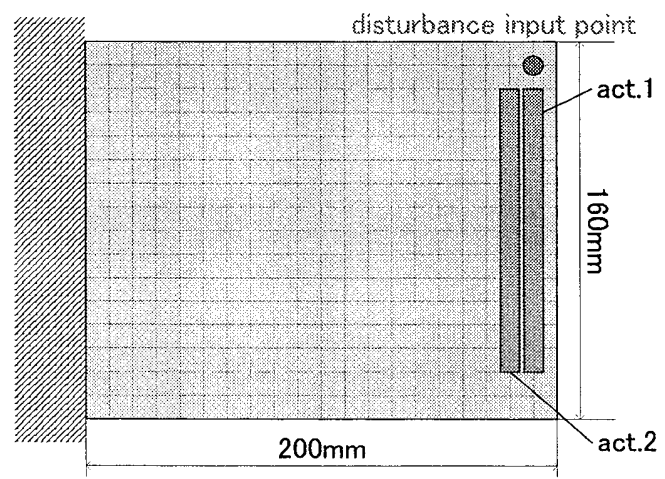

Fig.5 Optimal location of actuators

次に，最適化により得られたアクチュエータ配置および 制御系設計変数を用いて，加振点の自己アクセレランス周 波数応答, 平板から放射されるラウドネスレベルおよび音 響パワーレベルをそれぞれ Fig.6, Fig.7およびFig.8に示す. ここで，黒線は非制御時，赤線は制御時の応答を示す。

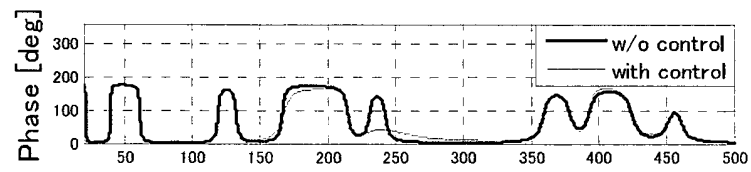
Frequency $[\mathrm{Hz}]$

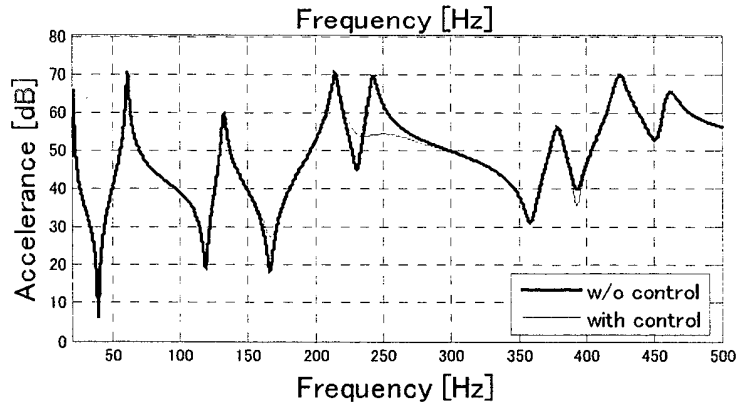

Fig.6 Accelerance at disturbance input point

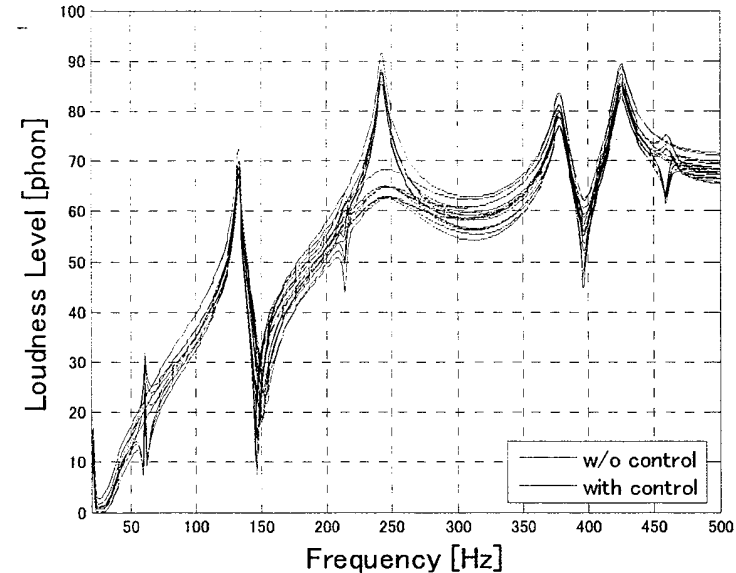

Fig.7 Loudness level at observed output points

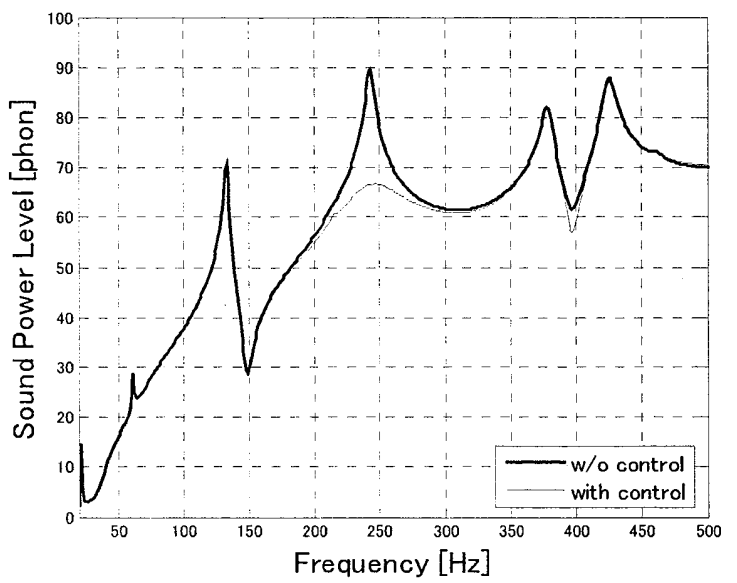

Fig.8 Frequency response of sound power level

最適化結果および周波数応答より，音響パワーレベルに対 して寄与の大きい 5 次共振モードを低減することで, 効率 的に放射騒音を低減できていることがわかる。制御入力は アクチュエータの両端でモーメントとして作用するため, たわみ角の差が大きい 2 点を結ぶようにアクチュエータを 配置すると効率的であるが，最適化により得られたアクチ ユエータ配置は 5 次のモード形に执いてわみ角が大きく なる 2 点を結ぶように配置されており，理にかなっている といえる。

また,アクチュエータに入力される制御入力の周波数応 答を Fig.9 に示す. 青線と緑線はそれぞれアクチュエータ 1 とアクチュエータ 2 の制御入力のグラフを示す.アクチ ユエータ配置が隣り合っているため, 制御入力の特性に大 きな違いは見受けられないが，制御入力を見ても5 次の共 振を低減するように制御エネルギ一を消費していることが わかる。 


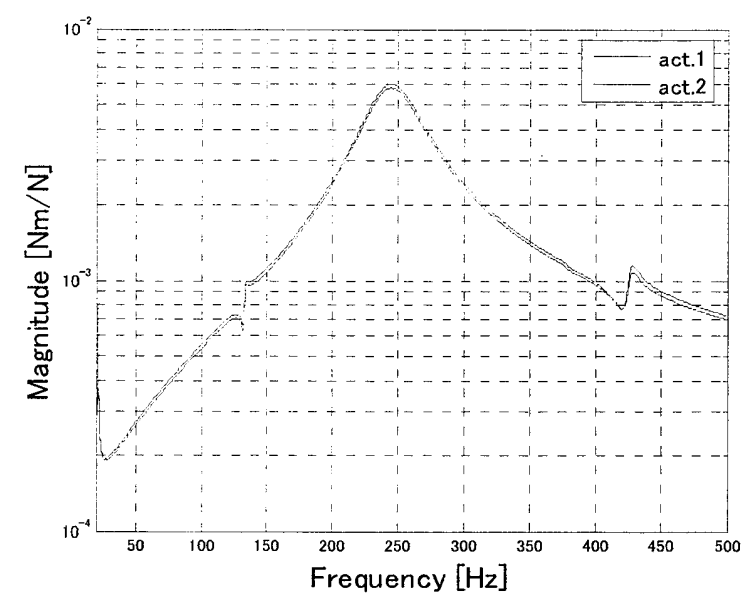

Fig.9 Frequency response of control inputs

\section{6. 結言}

1. スマート構造の最適化を行うことにより，構造から放 射される音響パワーレベルを抑制する方法について 検討を行った。

2. 効率的な騒音の抑制を達成すべく，圧電アクチュエー 夕の配置およびモード重み行列を含めた構造系と制 御系の複合領域最適化手法を提案した.

3. 最適化の目的関数として, 人間の聴覚特性を考慮する ことによって，騒音抑制に対して，より効果的なスマ 一ト構造最適化を実現した。

4. 提案手法をアルミニウム製片持ち平板に適用し, シミ ュレーションにより本手法の有効性を確認した。

\section{参考文献}

1) 梶原逸朗, 上原学, 大森隆広, 大橋史武, スマー卜構 造における圧電アクチュエータ形状／配置と制御系 の同時最適設計, 日本機械学会論文集 $(\mathrm{C}$ 編), 68 巻, 674 号, 2002, pp2925-2932.

2）梶原逸朗, 上原学, スマート構造における圧電アクチ ユエータ形状と制御系の同時最適設計（複数の圧電ア クチュエータを有する多入力系における検討), 日本 機械学会論文集 (C 編)，69 巻, 684 号, 2003, pp2093-2100.

3) 鈴木陽一，2次元ラウドネス曲線の全聴野精密決定, NEDO 国際共同研究助成事業（NEDO グラント）成果 報告, IS-01， 2003.

4) 時田保夫, 音の環境と制御技術 第 $I$ 巻 基礎技術, フジ・テクノシステム, 2000 .

5) International Organization for Standardization , Acoustics:ISO standards handbook, 1995.
6) 境久雄, 中山剛, 聴覚と音響心理, コロナ社, 1978 .

7) E. Zwicker, Subdivision of the Audible Frequency Range into Critical Bands (Frequenzgruppen), The journal of the acoustical society of America, volume 33, number 2, 1961, pp248. 